\title{
Laparoscopic sleeve gastrectomy and gastroesophageal reflux
}

\author{
ANDRADA-LOREDANA POPESCU ${ }^{1,2}$, FLORENTINA IONIȚA-RADU ${ }^{1,3}$, MARIANA JINGA $^{1,2}$, ANDREI-IONUȚ $^{2}$ \\ GAVRILA $^{1,2}$, FLORIN-ALEXANDRU SĂVULESCU ${ }^{1}$, CARMEN FIERBINȚEANU-BRATICEVICI $^{2,4}$ \\ ${ }^{1}$ Department of Gastroenterology, "Dr. Carol Davila” Emergency University Central Military Hospital, Bucharest, Romania \\ 2"Carol Davila" University of Medicine and Pharmacy, Bucharest, Romania \\ 3"Titu Maiorescu" University, Bucharest, Romania \\ ${ }^{4}$ Department of Gastroenterology, University Hospital Bucharest, Romania
}

\begin{abstract}
The prevalence of obesity is rising, becoming a medical problem worldwide. Also GERD incidence is higher in obese patients compared with normal weight, with an increased risk of 2.5 of developing symptoms and erosive esophagitis. Different treatment modalities have been proposed to treat obese patients, but bariatric surgery due to its complex interactions via anatomic, physiologic and neurohormonal changes achieved the best long-term results, with sustained weight loss and decrease of complications and mortality caused by obesity.

The bariatric surgical procedures can be restrictive: laparoscopic adjustable gastric band (LAGB) and laparoscopic sleeve gastrectomy (LSG), or malabsorptive-restrictive such as Roux-en-Y gastric bypass (RYGB). These surgical procedures may influence esophageal motility and lead to esophageal complications like gastroesophageal reflux disease (GERD) and erosive esophagitis. From the literature we know that the RYGB can ameliorate GERD symptoms, and some bariatric procedures were finally converted to RYGB because of refractory reflux symptoms. For LAGB the results are good at the beginning, but some patients experienced new reflux symptoms in the follow-up period.

Recently LSG has become more popular than other complex bariatric procedures, but some follow-up studies report a high risk of GERD after it. This article reviews the results published after LSG regarding gastroesophageal reflux and the mechanisms responsible for GERD in morbidly obese subjects.
\end{abstract}

Keywords: obesity; bariatric surgery; sleeve gastrectomy; gastroesophageal reflux; stomach.

\section{INTRODUCTION}

Obesity defined by WHO (World Health Organization) as BMI (body mass index) greater than 30 has become an important healthcare issue due to its complications [1]. Approximately $20 \%$ of the worldwide population is overweight $(\mathrm{BMI}>25)$ and $10 \%$ obese, unfortunately in the next 20 years approximately 2.16 billion people will be overweight and 1.12 billion obese [2].

Rising rates of obesity have led to an increased incidence of metabolic syndrome, type 2 diabetes mellitus, nonalcoholic fatty liver disease, hyperlipidemia and hypertension [3]. There is a considerable economic burden associated with obesity, with an average of $5 \%$ of the total health care cost going toward treating obese patients [4].

The prevalence of gastroesophageal reflux disease (GERD) and its related disorders is increasing in the United States, Western Europe and Scandinavian countries [5]. The physiopathological explanation is not clear, but there seems to be a direct association between BMI, particularly in the obese range and GERD symptoms (some of the mechanisms involved are lower esophageal sphincter pressure, presence of hiatal hernia - a good predictor of GERD, visceral fat, organomegaly and muscles elasticity responsible for gastroesophageal pressure-gradient).

Lifestyle modifications (low calorie diet and physical exercise) have been successfully used for weight loss for a long period of time, but despite an initial weight loss of typically $5 \%$ to $10 \%$ in the first 6 months, most weight is unfortunately regained $[6,7]$.

Drugs such as orlistat, lorcaserin and phentermine can be an alternative to diet and exercise, but they have an important risk for side effects (pulmonary disorders - pulmonary hypertension or cardiac disorders - valvulopathies) with no substantial weight loss and long term improvement of metabolic syndrome $[8,9]$.

Thus, bariatric surgery proved to be the most efficient in achieving significant and sustainable weight loss in severely obese patients, with good 
results, reducing comorbidities and improving mortality [10]. Bariatric surgery is currently recommended for obese patients defined as BMI (body mass index) higher than 40 or more than 35 with comorbidities (metabolic syndrome, type 2 diabetes mellitus, nonalcoholic fatty liver disease, hyperlipidemia and hypertension, sleep apnea).

The bariatric surgical procedures can be restrictive or malabsorptive. The restrictive bariatric procedures: laparoscopic adjustable gastric banding (LAGB) and laparoscopic sleeve gastrectomy (LSG) decrease the functional capacity of the stomach without a notable change in absorption. The malabsorptive-restrictive procedures include Roux-en-Y gastric bypass (RYGB) which is the most common, and biliopancreatic diversion (BPD) [10].

Laparoscopic adjustable gastric band (LAGB) is a minimally invasive bariatric procedure with rapid patient recovery after procedure, which involves placing an adjustable gastric band around the proximal stomach to divide it into a small pouch and a larger pouch. The inflatable band and of course the size of the pouches can be adjusted via subcutaneous access point as needed, the smaller proximal gastric pouch limits food intake and increases food transit time $[11,12]$.

Laparoscopic sleeve gastrectomy (LSG) is a surgical procedure that involves a vertical division on the larger curvature of the stomach, removing a large portion of the body and all of the fundus of the stomach (approximately 25\%) to create a smaller gastric pouch. This is a permanent effect, the remaining stomach is stapled closed, and the distal part is normal connected to the small bowel. LSG has a mixt weight loss mechanism, one restrictive and one endocrinologic reducing the level of an appetitestimulating hormone known as ghrelin [13].

LAGB and LSG do not affect the pyloric sphincter or intestinal absorption of nutrients.

Roux-en-Y gastric bypass (RYGB) is a restrictive-malabsorptive surgical procedure, in which the stomach is cut to form a pouch and a jejunal loop is connected to it. The proximal stomach transection leads to the restrictive effect and the bypassed small bowel with direct connection to the jejunal loop to the malabsorption [14].

All bariatric surgical procedures have a risk of postprocedural complications like stenosis at anastomotic sites, stomal ulcers, band erosions, and fistulae [15-17]. Despite anatomic differences, the bariatric procedures have in common alteration of the digestive tract and anatomic rearrangement, phenomena known by the acronim BRAVE: first letter was attributed from bile flow alteration (B), $\mathrm{R}$ from the reduction of the stomach size, A from anatomic gut rearrangement and altered flow of nutrients, $\mathrm{V}$ for vagal manipulations and $\mathrm{E}$ from enteric gut hormone modulation $[14,18]$.

Laparoscopic sleeve gastrectomy (LSG) proved to be efficient in weight loss and has gained popularity because of its advantages (simple surgical technique, without intestinal by-pass or anastomosis). Further we will discuss about the morbidity of LSG regarding especially GERD and the mechanisms involved.

\section{METHODS}

For this purpose we searched in PubMed for publications studying the effect of laparoscopic sleeve gastrectomy on GERD using the keywords "sleeve gastrectomy" and "gastroesophageal reflux". We selected a number of 20 articles, both prospective and retrospective studies, reviews and meta-analysis.

\section{GERD AND OBESITY}

The Montreal Classification defines GERD symptoms as heartburn and regurgitation because of the reflux contents of the stomach in the esophagus, symptoms interfering with physical activity, disturbing sleep, reducing productivity at work. GERD patients have usually altered antireflux mechanisms: LES (lower esophageal sphincter) pressure, phrenicoesophageal ligament, esophageal hiatus of the diaphragm, the angle of His, or physiological changes (esophageal dismotility with poor esophageal clearance, increased acid sensitivity of the esophageal mucosa, high gastric pressure or, rarely, high acid secretion: Zollinger-Ellison syndrome) [19].

Many studies investigated the connection between high incidence of obesity and GERD. For example, El-Serag et al. point out in a study published in 2005 that obese patients have a 2.5 increased risk of developing reflux symptoms and erosive esophagitis than normal weight people [20].

Nilsson et al., studying the effect of weight gain, found out that a rise of 3.5 BMI units leads to a 3-fold increased risk in developing new GERD symptoms [21]. In morbidly obese patients some of the pathophysiological mechanisms involved in GERD are: increased transient lower esophageal sphincter relaxations (TLESR), altered esophageal motility with poor esophageal clearance, the presence 
of hiatal hernia and increased intraabdominal pressure with altered gastroesophageal pressure gradient and delayed gastric emptying [22, 23]. Esophageal dismotility in morbid obesity has a prevalence in the literature varying between $20 \%$ to $61 \%$ [24, 25]. Some studies have shown that morbidly obese patients may have higher rates of hypotensive LES, but part of them do not have symptoms because of decreased sensation via altered sympathetic and parasympathetic innervations [25].

Greenstein et al. [26] in a prospective study evaluating obese patients selected for bariatric surgery performed esophageal manometry before operation and revealed varied changes of the esophagus: hypertensive LES (18\%), nutcracker esophagus $(5 \%)$, defective LES (16\%), ineffective esophageal disorder (2\%), diffuse esophageal spasm (3\%), and nonspecific motility disorder (23\%). Table 1 summarizes the mechanisms responsible for GERD.

Some behavioral factors may also affect LES pressure independent of the BMI value such as drugs: anticholinergic agents (tricyclic antidepressants, antihistamines), calcium channel antagonist, nitrates, oral contraceptives and estrogen, or food (chocolate, fatty foods, onions, peppermint, garlic), coffee consumption and smoking [5].

Table 1

Mechanisms responsible for GERD

\begin{tabular}{|l|l|l|l|}
\hline \multicolumn{1}{|c|}{ GERD in obesity } & \multicolumn{1}{|c|}{ GERD after LSG } & \multicolumn{1}{|c|}{$\begin{array}{c}\text { Improvement of } \\
\text { GERD after LSG }\end{array}$} \\
\hline \multirow{5}{*}{ Mechanism } & $\begin{array}{l}\text { Increased transient lower esophageal } \\
\text { sphincter relaxations (TLESR) [22] }\end{array}$ & LES pressure & $\begin{array}{l}\text { Reduced acid } \\
\text { production }\end{array}$ \\
\cline { 2 - 5 } & Poor esophageal clearance [22, 23] & $\begin{array}{l}\text { Modifying the angle of His and dissecting of } \\
\text { ligaments [30] }\end{array}$ & $\begin{array}{l}\text { Reduced gastric } \\
\text { volume }\end{array}$ \\
\cline { 2 - 5 } & Hiatal hernia & Persistence of hiatal hernia & \\
\cline { 2 - 5 } & $\begin{array}{l}\text { Increased intraabdominal pressure with } \\
\text { altered gastroesophageal pressure gradient } \\
\text { [22] }\end{array}$ & $\begin{array}{l}\text { Increased intraluminal pressure (small gastric } \\
\text { pouch and poor compliance) [30] }\end{array}$ & $\begin{array}{l}\text { Reduced } \\
\text { intraabdominal } \\
\text { pressure [30] }\end{array}$ \\
\cline { 2 - 5 } & Delayed gastric emptying [23] & $\begin{array}{l}\text { Narrowing at the junction of the vertical and } \\
\text { horizontal parts of the sleeve }\end{array}$ & $\begin{array}{l}\text { Accelerated gastric } \\
\text { emptying [30] }\end{array}$ \\
\hline
\end{tabular}

\section{LAPAROSCOPIC SLEEVE GASTRECTOMY AND GERD}

In the literature the risk of possible complications after LSG is approximately $13 \%$, and the postoperative mortality $0.34 \%$ [27]. The majority of complications associated with LSG occur in the late postoperative period: gastroesophageal reflux, stenosis, vomiting, gastric tube stricture, gastrocutaneous fistula and weight regain $[28,29]$.

In a review of Chiu et al. from 2011 [30] 4 studies showed high prevalence and 7 studies low prevalence of esophageal reflux after LSG. The explanation for high prevalence of GERD is that LSG influence LES pressure by modifying the angle of His and dissecting of ligaments (see Table 1). At the same time, the small gastric pouch has high pressure inside, because of the reduced volume, and is associated with poor gastric compliance and emptying [30].

Regarding the lower prevalence of GERD after LSG, we must take into account that the weight loss achieved will decrease the abdominal pressure, and another hypothesis is that LSG is associated with accelerated gastric emptying, but this aspect needs further studies in the future. In approximately 3 years postoperatively it seems that the angle of His is restored, and good compliance promotes long-term resolution of GERD [30].

DuPree CE. et al. [33] in 2014 analyzed the effect of laparoscopic sleeve gastrectomy (LSG) on patients with gastroesophageal reflux disease (GERD) and compared the results of LSG with gastric bypass (GB). From a total of 4832 patients who underwent LSG, $44.5 \%$ had preexisting GERD. Of those, $84.1 \%$ continued to have GERD symptoms after LSG, with only $15.9 \%$ demonstrating GERD resolution. Of LSG with no GERD symptoms preoperative, $8.6 \%$ developed de novo GERD postoperatively. In comparison, GB resolved GERD in most patients $(62.8 \%)$ within 6 months postoperatively $(\mathrm{P}<.001)$.

Another study from 2014 made on 71 patients by Rebecchi F et al. [34] showed that LSG improves symptoms and controls the reflux in most morbidly obese patients with preoperative GERD, but the 
cohort was small. The DeMeester score and total acid exposure $(\% \mathrm{pH}<4)$ decreased from $39.5 \pm 16.5$ to $10.6 \pm 5.8, \mathrm{P}<0.001$; respectively $\% \mathrm{pH}<4$ from
$10.2 \pm 3.7$ to $4.2 \pm 2.6, \mathrm{P}<0.001)$, and "de novo" GERD symptoms occurred in $5.4 \%$ patients. Table 2 summarizes the results found for LSG and GERD.

Table 2

Papers found for LSG and GERD

\begin{tabular}{|c|c|c|c|c|c|}
\hline Reference & $\begin{array}{c}\text { Nature of the } \\
\text { study }\end{array}$ & Patients, $n$ & $\begin{array}{l}\text { Period of } \\
\text { study }\end{array}$ & GERD evaluation & Impact pos + neg- \\
\hline $\begin{array}{l}\text { Braghetto I. et al. [28], } \\
2010\end{array}$ & Prospective study & 20 & 6 months & RDQ; EM & - \\
\hline $\begin{array}{l}\text { Triantafyllidis G. et al. } \\
\text { [29], } 2011\end{array}$ & $\begin{array}{l}\text { Retrospective } \\
\text { review }\end{array}$ & 85 & & $\begin{array}{l}\text { UGICS(day3 postop) or CT } \\
\text { and RDQ }\end{array}$ & - \\
\hline $\begin{array}{l}\text { Chiu S. et al. [30], } \\
2011\end{array}$ & Literature review & & & & 4 studies -7 studies + \\
\hline $\begin{array}{l}\text { Chopra A. et al. [31], } \\
2012\end{array}$ & $\begin{array}{l}\text { Retrospective } \\
\text { review and analysis }\end{array}$ & 185 & 6 months & RDQ; EGD & $\begin{array}{l}\text { + Improvement: } 46 \% \\
\text { De novo: } 3.2 \%\end{array}$ \\
\hline $\begin{array}{l}\text { Carabotti M. et al. } \\
{[32], 2013}\end{array}$ & Retrospective & 97 & $\begin{array}{l}13 \text { months } \\
\text { follow-up }\end{array}$ & RDQ & No impact on GERD \\
\hline $\begin{array}{l}\text { DuPree CE. et al. [33], } \\
2014\end{array}$ & $\begin{array}{l}\text { Retrospective } \\
\text { review }\end{array}$ & 4832 & 36 months & $\begin{array}{l}\text { 44.5\% had preexisting } \\
\text { GERD. } \\
\text { RDQ; EGD }\end{array}$ & $\begin{array}{l}84.1 \% \text { persisted } 15.9 \% \\
\text { GERD resoluted De novo } \\
8.6 \%\end{array}$ \\
\hline $\begin{array}{l}\text { Rebecchi F. et al. [34], } \\
2014\end{array}$ & \begin{tabular}{|l|}
$\begin{array}{l}\text { Prospective } \\
\text { study }\end{array}$ \\
\end{tabular} & 71 & 24 months & RDQ ; EGD; EM; 24-h pH & (1) \\
\hline Sieber et al. [35], 2014 & \begin{tabular}{|l|}
$\begin{array}{l}\text { Retrospective } \\
\text { review }\end{array}$ \\
\end{tabular} & 68 & 5 years & EGD, UGICS, EM & - \\
\hline $\begin{array}{l}\text { Sharma et al. [36], } \\
2014\end{array}$ & Prospective study & 32 & $3 / 12$ months & RDQ; EGD; RS & + \\
\hline $\begin{array}{l}\text { Soricelli E. et al. [37], } \\
2018\end{array}$ & Prospective & 142 & 66 months & RDQ; PPI intake; EGD & - \\
\hline
\end{tabular}

RDQ Reflux-disease questionnaire; Demeester score; EGD esophagogastroduodenoscopy;

EM esophageal manometry; 24-h pH; RS Radionuclide scintigraphy; UGICS Upper gastrointestinal contrast study (gastrografin swallow/barium); CT computed tomography; PPI proton pomp inhibitor.

\section{CONCLUSIONS}

We have controversial data regarding LSG and GERD (see Table 2), the current studies available showing different results, so further research on this topic is required.

We need more studies to evaluate the effects of LSG on gastrointestinal motility, especially to conclude about the connection with ineffective peristalsis. Esophageal dysmotility (discoordination and alteration of contraction strength or duration) may also lead to gastrointestinal symptoms like heartburn, nausea, vomiting, dysphagia, odynophagia [32]. These correlations were made by Carabotti et al., in their study dysphagia appeared in $19.7 \%$ of patients after LSG, manifested as retrosternal discomfort after liquids and solids, and dyspepsia was found at $59.4 \%$, because of high pressure in the small stomach after sleeve [32], high pressure also linked to the simultaneous gastric and pyloric contractions [38].

Laparoscopic sleeve gastrectomy leads to stable and adequate weight loss, some data published by Chopra et al. [31] showed high resolution of comorbidities: $84 \%$ for diabetes mellitus, $49.99 \%$ for hypertension, $90 \%$ for asthma, $90.74 \%$ for obstructive sleep apnea, and $45.92 \%$ for gastroesophageal reflux disease symptoms (GERD), with only six new onsets of GERD symptoms (3.24\%).

In conclusion, bariatric surgery has become safer as surgeons gain experience in the evaluation and treatment of obese patients, but careful medical assessment is mandatory before choosing the type of bariatric surgery, especially for those patients who already have GERD.

Conflict of Interest disclosure: The authors declare that there are not conflicts of interest.

Prevalența obezității este în creştere, devenind o reală problemă de sănătate publică. Incidența BRGE (bolii de reflux gastroesofagian) este mai mare la 
pacienții obezi comparativ cu cei normoponderali, cu o creştere de 2.5 ori a riscului de dezvoltare a simptomelor şi a esofagitei erozive.

S-au propus mai multe modalități de tratament pentru obezitate, dar chirurgia bariatrică datorită interacțiunilor complexe anatomice, fiziologice şi neurohormonale a demonstrat cele mai bune rezultate pe termen lung, cu scădere ponderală susținută şi reducerea morbidității şi mortalității cauzate de obezitate.

Metodele de chirurgie bariatrică pot fi pur restrictive, cum ar fi LAGB (inelul gastric laparoscopic ajustabil) sau LSG (gastrectomia sleeve laparoscopică), sau restrictiv-malabsorptive cum ar fi Roux-en-Y gastric bypass (RYGB)(2). Aceste tehnici chirurgicale pot avea efecte nedorite asupra esofagului, mai ales in ceea ce priveşte boala de reflux gastroesofagian şi motilitatea esofagiană.

Unele studii apreciază că Roux-en-Y gastric bypass este o metodă chirurgicală utilă în ameliorarea simptomelor de reflux; inelul gastric laparoscopic poate ameliora inițial simptomele de reflux, deşi un subgrup de pacienți a dezvoltat simptome noi postoperator.

În ultimii ani gastrectomia sleeve a devenit cea mai populară procedură chirurgicală bariatrică, dar câteva studii au demonstrat creşterea riscului de BRGE postintervenție. Acest articol îşi propune un studiu al datelor disponibile în literatură privind acest risc şi mecanismele responsabile de reflux la pacienții obezi. O evaluare medicală completă preoperator la pacienții cu obezitate morbidă ajută la alegerea tipului de intervenție chirurgicală bariatrică, reducând astfel prevalența complicațiilor dispeptice.

Correspondence to: Popescu Andrada Loredana, M.D, "Dr. Carol Davila” Emergency University Central Military Hospital, Department of Gastroenterology, 133 Calea Plevnei Street, Bucharest, Romania, postal zip code 010225 Phone: +040762603955

E-mail: popescu_andrada13@yahoo.com

\section{REFERENCES}

1. World Health Organization. Report on Obesity and Overweight. Geneva: The Organization; 2011 (no 311 of fact sheet series).

2. KELLY T., YANG W., CHEN C.S., et al. Global burden of obesity in 2005 and projections to 2030. Int J Obes (Lond) 2008; 32:1431-7.

3. FORD E.S. Risk for all-cause mortality, cardiovascular disease and diabetes associated with the metabolic syndrome: a summary of the evidence. Diabetes Care. 2005; 28(7): 1769-1778.

4. Obesity: preventing and managing the global epidemic. Report of WHO consultation. World Health organ Tech Rep Ser. 2000; 894:i-xii, 1-253.

5. DENT J., EL-SERAG H.B., WALLANDER M.A., JOHANSSON S. Epidemiology of gastro-oesophageal reflux disease: a systematic review. Gut. 2005 May; 54(5):710-7.

6. DYSON P.A. The therapeutics of lifestyle management on obesity. Diabetes Obes metab. 2010; 12(11):941-946.

7. WING R.R., PHELAN S. Long-term weight loss maintenance. Am. J. Cl. Nutr. 2005; 82(1 suppl.):222S-225S.

8. RICH S., RUBIN L., WALKER A.M., SCHNEEWEISS S., ABENHAIM L. Anorexigenes and pulomonary hypertension in the United States results from the surveillance of North American pulmonary hypertension. Chest 2000; 117(3):870-874.

9. SACHDEV M., MILLER W.C., RYAN T., JOLLIS J.G. Effect of fenfluramine-derivative diet pills on cardiac valves: a metaanalysis of observational studies. Am. Heart. J 2002; 144 (6):1065-1073.

10. BUCHWALD H., AVIDOR Y., BRAUNWALD E., et al. Bariatric surgery: a systematic review and meta-analysis. JAMA. 2004; 292:1724-37.

11. LO MENZO E., SZOMSTEIN S., ROSENTHAL R.J., Changing trends in bariatric surgery. Scand J Surg.2015; 104(1):18-23.

12. MILLER K. Obesity: surgical options. Best Pract Res Clin Gastroenterol. 2004; 18(6):1147-1165.

13. LANGER F.B., REZA HODA M.A., BOHDJALIAN A., et al. Sleeve gastrectomy and gastric banding: effects on plasma ghrelin levels. Obes Surg. 2005; 15:1024-9 [PubMed].

14. RISHI D.N, YASH A.C, MICHAEL F.V. Impact of weight loss surgery on esophageal physiology. Gastroenterology \& Hepatology 2015 Dec, Vol. 11, Issue 12.

15. WESTLING A., BJURLING K., OHRVALL M., GUSTAVSSON S. Silicone-adjustable gastric banding: disappointing results. Obes Surg. 1998; 8(4):467-474.

16. FILHO A.J., KONDO W., NASSIS L.S., GARCIA M.J., TIRAPULLE R DE A., DOTTI C.M. Gastrogastric fistula: a possible complication of Roux-en-Y gastric bypass. JSLS. 2006; 10(3):326-331. 
17. GUMBS A.A., DUFFY A.J., BELL R.L., Incidence and management of marginal ulceration after laparoscopic Roux-en-Y gastric bypass, Surg Obes Relat Dis. 2006; 2(4):460-463.

18. KORNER J. INABNET W., FEBRES G., et al. Prospective study of gut hormone and metabolic changes after adjustable gastric banding and Roux-en-Y gastric bypass. Int J Obes (Lond). 2009; 33(7); 786-795.

19. VAKIL N., VAN ZANTEN S.V., KAHRILS P., et al. The Montreal definition and classification of gastroesophageal reflux disease: a global evidence-based consensus. Am J Gastroenterol.2006; 101(8):1900-1920.

20. EL-SERAG H.B., GRAHAM D.Y., SATIA J.A., RABENECK L. Obesity is an independent risk factor for GERD symptoms and erosive esophagitis. Am. J. Gastroenterol. 2005; 100(6), 1243-1250 .

21. NILSSON M., JOHNSEN R., YE W., HVEEM K., LAGERGREN J., Obesity and estrogen as risk factors for gastroesophageal reflux symptoms. JAMA. 2003 Jul 2; 290(1):66-72.

22. WILSON L.J., MA W., HIRSCHOWITZ B.I., Association of obesity with hiatal hernia and esophagitis. Am J Gastroenterol. 1999; 94(10):2840-2844.

23. MERCER C.D., RUE C., HANELIN L., HILL L.D. Effect of obesity on esophageal transit. Am J Surg 1985; 149(1):177-181.

24. JAFFIN B.W., KNOEPFLMACHER P., GREENSTEIN R. High prevalence of asymptomatic esophageal motility disorders among morbidly patients. Obes surg.1999; 9(4):390-395.

25. ALMOGY G., ANTHONE G.J., CROOKES P.F. Achalasia in the context of morbid obesity: a rare but important association. Obes Surg.2003; 13(6):896-900.

26. GREENSTEIN R.J., NISSAN A., JAFFIN B. Esophageal anatomy and function in laparoscopic gastric restrictive bariatric surgery: implications for patient selection. Obes Surg. 1998; 8(2):199-206

27. CHANG S.H., STOLL C.R., SONG J., VARELA J.E., EAGON C.J. COLDITZ G.A. The effectiveness and risks of bariaric surgery: an updated systematic review and meta-analysis. 2003-2012. JAMA Surg. 2014; 149(3):275-287.

28. BRAGHETTO I, LANZARINI E, KORN O, VALLADARES H, MOLINA JC, HENRIQUEZ A. Manometric changes of the lower esophageal sphincter after sleeve gastrectomy in obese patients. Obes Surg. 2010; 20:357-362.

29. TRIANTAFYLLIDIS G., LAZOURA O., SIOKA E., et al. Anatomy and complications following laparoscopic sleeve gastrectomy: radiological evaluation and imaging pitfalls. Obes Surg 2011; 21(4):473-478.

30. CHIU S., BIRCH D.W., SHI X., et al. Effect of sleeve gastrectomy on gastroesophageal reflux disease: a systematic review. Surg Obes Relat Dis. 2011; 7:510-5.

31. CHOPRA A, CHAO E, ETKIN Y, MERKLINGER L, LIEB J, DELANY H. Laparoscopic sleeve gastrectomy for obesity: can it be considered a definitive procedure? Surg Endosc. 2012; 26:831-837.

32. CARABOTTI M., SILECCHIA G., GRECO F., et al. Impact of laparoscopic sleeve gastrectomy on upper gastrointestinal symptoms. Obesity Surgery. 2013; 23(10):1551-1557.

33. DUPREE CE., BLAIR K., STEELE SR., MARTIN MJ. Laparoscopic sleeve gastrectomy in patients with preexisting gastroesophageal reflux disease: a national analysis. JAMA Surg. 2014 Apr; 149(4):328-34.

34. REBECCHI F., ALLAIX ME., GIACCONE C., UGLIONO E., SCOZZARI G., MORINO M. Gastroesophageal reflux disease and laparoscopic sleeve gastrectomy: a physiopathologic evaluation. Ann Surg. 2014 Nov; 260(5):909-14.

35. SIEBER P, GASS M, KERN B, PETERS T, SLAWIK M, PETERLI R. Five-year results of laparoscopic sleeve gastrectomy. Surg Obes Relat Dis. 2011; 10:243-249.

36. SHARMA A, AGGARWAL S, AHUJA V, BAL C. Evaluation of gastroesophageal reflux before and after sleeve gastrectomy using symptom scoring, scintigraphy, and endoscopy. Surg Obes Relat Dis. 2014; 10(4):600-5.

37. SORICELli E., CASELLA G., BAGLIO G., MASELLI R., ERNESTI I., GENCO A., Lack of correlation between gastroesophageal reflux disease symptoms and esophageal lesions after sleeve gastrectomy. Surg Obes Relat Dis. 2018 Feb 13. pii: S1550-7289(18)30087-X. 2014; 10:600-605.

38. WEINER R., EL-SAYES I., AND WEINER S., LSG: complications - diagnosis and management, in Obesity, bariatric and metabolic surgery - a practical guide, S. Agrawal, 2015. Ed; pp. 259-272, Springer, Basel, Switzerland, 1st edition.

Received April 21, 2018 